\title{
UI TANAMAN COONTAIL (CERATOPHYLLUM DEMERSUM) SEBAGAI AGEN FITOREMEDIASI LIMBAH CAIR KOPI
}

\author{
Suryadi ${ }^{1)}$, Isna Apriani ${ }^{1)}$, Ulli Kadaria $^{1)}$ \\ ${ }^{1)}$ Program Studi Teknik Lingkungan Jurusan Teknik Sipil Fakultas Teknik Universitas Tanjungpura, Pontianak \\ Email :Suryadia36@gmail.com
}

\begin{abstract}
ABSTRAK
Limbah cair kopi dihasilkan dari pengolahan biji kopi cara basah yakni pada proses pengelupasan (pulping) dan pencucian (washing) biji kopi. Komponen utama dalam limbah cair kopi adalah berupa bahan organik yang dapat beresiko meningkatkan kadar pencemaran lingkungan dalam suatu perairan. Berdasarkan Peraturan Menteri Lingkungan Hidup No. 5 Tahun 2014 tentang baku mutu limbah cair kopi yang diperbolehkan untuk dibuang adalah BOD sebesar $90 \mathrm{mg} / \mathrm{L}$ dan nilai rentang $\mathrm{pH}$ sebesar 6-9. Tujuan dari penelitian ini adalah mengetahui seberapa besar efisiensi penurunan BOD dan peningkatan nilai pH limbah cair kopiserta untuk mengetahui waktu pemaparan optimum tanaman coontail(Ceratophyllum demersum) dalam menurunkan parameter BOD dan peningkatan nilai $\mathrm{pH}$ limbah cair kopi. Penelitian ini menggunakan fitoremediasi dengan sistem batch yang terdiri dari 3 unit reaktor kontrol (tanaman dan air bersih) dan 3 unit reaktor uji (tanaman dan limbah kopi) dengan variasi waktu pemaparan selama 12 hari, 15 hari, dan 18 hari yang dilakukan dengan dua kali pengulangan (duplo) yang kemudian dianalisis dengan menggunakan perhitungan rumus efisiensi dan dengan mengamati kondisi tanaman coontail. Hasil penelitian diperoleh data peningkatan nilai $\mathrm{pH}$ pada hari ke 12 sebesar 3,7 (dari 4,2 menjadi 7,9), pada hari ke 15 meningkat sebesar 4,1 (dari 4,2 menjadi 8,3), dan pada hari ke 18 meningkat mencapai 4,3 (dari 4,2 menjadi 8,5 ). Sedangkan nilai penurunan BOD pada hari ke 12 sebesar 45,5\% (dari 466,06 mg/L menjadi $253,915 \mathrm{mg} / \mathrm{L}$ ), pada hari ke 15 sebesar 52,86\% (dari 466,06 mg/L menjadi 219,075 mg/L), dan pada hari ke 18 sebesar 66,94\% (dari 466,06 mg/L menjadi 154,085 mg/L). Berdasarkan data tersebut, dapat diketahui nilai efisiensi penurunan BOD dan peningkatan $\mathrm{pH}$ tertinggi pada hari ke 18 .
\end{abstract}

Kata kunci:Fitoremediasi coontail (Ceratophyllum demersum), BOD, pH, Limbah Cair Kopi

\begin{abstract}
Liquid waste generated from processing coffee beans how to wet in the peeling process and washing of coffee beans. The main components in the liquid waste of coffee is in the form of organic matter that may be at risk of increasing levels of environmental pollution in a water. Based on the regulation of the Minister of the environment, number 5 by 2014 about quality raw coffee liquid waste is allowed to be discarded is the BOD of $90 \mathrm{mg} / \mathrm{L}$ and $\mathrm{pH}$ range of 6-9. The purpose of this research is to know how large the efficiency decrease of the $\mathrm{pH}$ value and improvement of $B O D$ of waste liquid of coffee as well as optimum exposure time for knowing the plant coontail (Ceratophyllum demersum), in the lower parameters BOD and $\mathrm{pH}$ value of waste liquid coffee. This research uses a fitoremediasi system with system batch consisting of 3 units of reactor control (plants and clean water) and 3 unit test reactor (plants and waste copies) with a variation of the exposure time for 12 days, 15 days, and 18 days is done with two repetitions (duplo) which is then analyzed by using a calculation formula of efficiency and by observing the condition of the plant coontail. The research results obtained data an increased $\mathrm{pH}$ values on day 12 of 3.7 (from 4.2 to become 7, 9), on day 15 increased by 4.1 (from 4.2 becomes 8.3), and on the 18th the rise reaches 4.3 (from 4.2 be 8,5). While the decline in the value of BOD on day 12 of $45.5 \%$ (from $466.06 \mathrm{mg} / \mathrm{L} \mathrm{be} 253.915 \mathrm{mg} / \mathrm{L}$ ), on the
\end{abstract}


15th day of $52.86 \%$ (from $466.06 \mathrm{mg} / \mathrm{L}$ be $219.075 \mathrm{mg} / \mathrm{L}$ ), and on day 18 of $66.94 \%$ (from $466.06 \mathrm{mg} / \mathrm{L}$ be $154.085 \mathrm{mg} / \mathrm{L}$ ). Based on these data, decreasing efficiency rating known BOD and $\mathrm{pH}$ increase highest on day 18.

Keywords: Fitoremediasi coontail (Ceratophyllum demersum), $B O D, p H$, liquid waste Coffee

\section{- PENDAHULUAN}

Kalimantan Barat memiliki lahan kopi yang cukup besar, berdasarkan data Badan Pusat Stastik Kalbar tahun 2013 total luas lahan perkebunan kopi di Kalimantan Barat sebesar $12.407 \mathrm{Ha}$, sedangkan luas lahan perkebunan terbesar berada di Kabupaten Kubu Raya dengan luas area perkebunan sekitar 5,369 Ha. Hampir semua kabupaten di Kalimantan Barat dijumpai produk kopi yang dibudidaya oleh petani dengan rata-rata produktivitas kopi sebesar 0,373 Ton/Ha.

Meningkatnya permintaan pasar akan kebutuhan kopi dapat berdampak pada peningkatan industri pengolahan biji kopi. Jika tidak ditanggulangi maka, dengan banyaknya industri kopi akan berdampak pada meningkatnya limbah baik limbah cair maupun limbah padat dari proses pengolahan biji kopi. Apabila limbah hasil cuci biji kopi tidak diolah terlebih dahulu maka akan berdampak pada pencemaran lingkungan. Hal ini dikarenakan limbah cair kopi memiliki kandungan konsentrasi zat organik yang tinggi seperti tingkat keasaman yang rendah, dan kandungan glukosa(Widyotomo, 2012).

Tingginya kandungan bahan organik pada limbah cair kopi dapat menyebabkan pencemaran berupa polusi organik pada perairan dimana limbah kopi tersebut dibuang. Peraturan Menteri Lingkungan Hidup Republik Indonesia No. 5 Tahun 2014 Tentang Baku Mutu Air Limbah Bagi Usaha dan/atau Kegiatan Industri Pengolahan Kopi baku mutu limbah cair kopi yang diperbolehkan untuk dibuang ke lingkungan adalah BOD sebesar 90 mg/L.untuk mengolah dan menanggulangi kandungan organik yang terkandung dalam air limbah maka diperlukan suatu pengolahan berupa fitoremediasi.

Fitoremediasi adalah salah satu metode penanganan limbah secara alami dengan memanfaatkan tumbuh-tumbuhan sebagai agen penurun kadar zat berbahaya yang ada didalam limbah.Tumbuhan yang digunakan dalam penelitian ini adalah tanaman coontail (Ceratophyllum demersum).Tumbuhan ini dipilih karena mudah dicari keberadaannya, banyak tumbuh disekitar sungai kecil serta parit-parit, mudah beradaptasi dengan lingkungan serta tanaman ini memiliki tingkat efisiensi yang cukup tinggi dalam menurunkan parameter BOD.

Tujuan penelitian ini adalah untuk mengetahui kemampuan tanaman coontail (Ceratophyllum demersum)dalam menurunkan parameter BOD sebagai parameter terukur dan $\mathrm{pH}$ dan suhu sebagai parameter yang diamati, serta untuk mengetahui waktu kontak optimum yang dibutuhkan tanaman dalam menurunkan parameter BOD sebagai parameter terukur serta $\mathrm{pH}$ dan suhu sebagai parameter yang diamati.

\section{- METODE PENELITIAN \\ $>\quad$ Waktu dan Tempat}

Penelitian dilaksanakan selama 2 bulan dimulai pada bulan Agustus hingga Oktober 2016 bertempat di Workshop (WS) Teknik Lingkungan.Pengujian parameter $\mathrm{pH}$ dan suhu dilakukan di Laboratorium Teknik Lingkungan Universitas Tanjungpura Pontianak dan analisis BOD dilakukan di Laboratorium Kualitas dan Kesehatan Lahan Fakultas Pertanian Universitas Tanjungpura Pontianak.

\section{$>\quad$ Alat dan Bahan Penelitian}

Alat yang digunakan dalam penelitian ini adalah bak fitoremediasi berbahan dasar plastik transparan sebanyak 12 unit yang terdiri dari6 unit reaktor kontrol yang berisi tanaman dan air bersih dan 6 unit reaktor uji ( 3 reaktor uji utama dan 3 reaktor pengulangan), gelas ukur, lem pipa, keran air 6 buah, penggaris, $\mathrm{pH}$ meter digunakan untuk mengukur pH sampel air, jeriken volume $20 \mathrm{~L} 2$ unit 
untuk menampung dan mengangkut limbah cair kopi, botol air mineral $600 \mathrm{ml}$ untuk uji laboratorium.

Bahan yang digunakan adalah akudes,tanaman coontail yang didapat dari parit-parit disekitar jalan Rasau Jaya, Kabupaten Kubu Raya,limbah cair kopi diperoleh dari perkebunan kopi rakyat yang berada di Desa Punggur Besar, Kabupaten Kubu Raya.

\section{$>\quad$ Variable penelitian}

Jenis variabel yang digunakan dalam penelitian ini adalah variabel bebas dan variabel terikat.Variabel bebas adalah variabel yang nilainya divariasi dalam penelitian ini, variable bebas yang diteliti yaitu waktu pemaparan 12 hari, 15 hari dan 18 hari.Variabel terikat adalah variabel yang menjadi titik fokus penelitian, dalam hal ini variabel terikat yaitu penurunan angka BOD serta pengamatan nilai suhu dan $\mathrm{pH}$.

\section{Prosedur penelitian}

Penelitian ini merupakan eksperimen penyisihan BOD pada limbah cair kopi dan dilaksanakan dalamskala laboratorium dalam batasan waktu tertentu. Pelaksanaan penelitian ini terdiri dari 4 tahapanyaitu persiapan alat dan bahan, aklimatisasi tanaman, proses fitoremediasi dan analisis sampel. Adapun prosedur penelitiannya sebagaiberikut:

a. Persiapan alat dan bahan

Persiapan alat dan bahan meliputipengambilan tanaman coontail di parit Rasau Jaya, serta pembelian bak fitoremediasi berbahan dasar plastik transparan dengan ukuran panjang 30 $\mathrm{cm} \times$ lebar $25 \mathrm{~cm} \times$ tinggi $15 \mathrm{~cm}$.

b. Pengambilan tanaman coontail berdasarkan warna dan panjang tanaman. Tanaman yang dipilih memiliki warna hijau terang guna memastikan tanaman dalam kondisi yang sehat. Selanjutnya tanaman dibersihkan dengan air bersih guna menghilangkan lumpur dan tanah yang masih melekat

c. Proses aklimatisasi tanaman berlangsung selama 7 hari untuk memastikan tanaman dapat beradaptasi kedalam lingkungan berbeda. Proses aklimatisasi digunakan dengan menumbuhkan tanaman coontail kedalam akuades

d. Setelah selesai dilakukannya proses aklimatisasi selama 7 hari maka, barulah kemudian dimulai proses penelitian fitoremediasi dengan prosedur penelitian sebagai berikut:

- Pengukuran awal parameter BOD, pH dan suhu limbah cair kopi

- Limbah cair kopi dituang kedalam masing-masing bak reaktor yang telah disiapkan sebanyak 5 L/unit. Adapun jumlah reaktor yang digunakan adalah sebanyak 12unit reaktor seperti terlihat pada Gambar 1 yang terdiri dari 6 reaktor uji (3 reaktor utama dan 3 reaktor pengulangan) yang dibedakanberdasarkan variasi lama waktu tinggal tanaman (12 hari, 15 hari dan 18 hari) dan 6 unit reaktor yang terdiri dari 3 reaktor kontrol utama dan 3 reaktor kontrol pengulangan yang di bedakanberdasarkan variasi lama waktu tinggal tanaman (12 hari, 15 hari dan 18

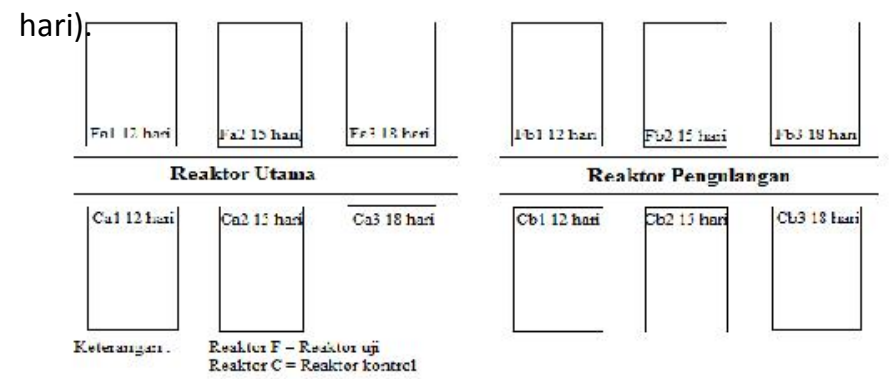

Gambar 1. Reaktor Utama dan Reaktor Pembanding 
- Tanaman coontail yang telah diaklimatisasi kemudian dipindahkan ke dalam masing-masing reaktor sebanyak $60 \mathrm{gr}$ dengan panjang tanaman $10 \mathrm{~cm} /$ tanaman dan dibiarkan terpapar oleh limbah dengan lama variasi waktu pemaparan yaitu 12 hari (F.1), 15 hari (F.2) dan 18 hari (F.3) seperti terlihat pada Gambar 1.

- Tahapan selanjutnya yaitu menganalisa parameter BODpada sampel limbah cair pada masing-masing reaktor berdasarkan variasi waktu pemaparan serta pengukuran $\mathrm{pH}$ dan suhu dilakukan setiap haridilanjutkan dengan prosespengamatan kondisi tanaman berupa panjang dan perubahan warna tanamancoontailyang berada dalam reaktor kontrol dan yang berada di dalam reaktor uji.

\section{$>\quad$ Analisa Data}

Untuk mengetahui efisiensi penurunan BOD limbah cair kopi digunakan rumus sebagai berikut.

$E f=\frac{C_{0}-C_{i}}{C_{0}} \times 100 \%$

Dimana:

Ef $\quad=$ Efisiensi Proses Penurunan Parameter (\%)

Co $\quad=$ Konsentrasi Parameter Saat Masuk ke Proses

$\mathrm{Ci} \quad=$ Konsentrasi Parameter Saat Keluar dari Proses.

\section{- HASIL DAN PEMBAHASAN}

Sampel limbah cair kopi diambil dari perkebunan kopi yang berada di Desa Punggur Kecil, Kabupaten Kubu Raya. Limbah cair kopi dihasilkan dari proses pengelupasan (pulping) danproses pencucian (washing). Sampel dianalisis di Laboratorium Kualitas dan Kesehatan Lahan Fakultas Pertanian Universitas Tanjungpura Pontianak dengan hasil sebagaiberikut:

Tabel 1. Karakteristik Limbah Cair Kopi

\begin{tabular}{|c|c|c|c|}
\hline Parameter Pengukuran & Hasil Uji & Baku Mutu (*) & Satuan \\
\hline BOD & 466,06 & 90 & $\mathrm{mg} / \mathrm{l}$ \\
\hline $\mathrm{pH}$ & 4,2 & $6-9$ & \\
\hline
\end{tabular}

* Permen LH No. 5 tahun 2014

Berdasarkan Tabel1 menunjukkan bahwa pada parameter BOD baku mutu limbah cair kopi yang diperbolehkan untuk dibuang kelingkungan adalah $90 \mathrm{mg} / \mathrm{L}$, sementara pada nilai karakteristik awal limbah cair kopi memiliki kandungan BOD yang cukup tinggi yakni kisaran 466,06 mg/L. Sementara untuk nilai pH limbah cair kopi adalah sebesar 4,2 yang berarti tidak berada pada rentang standar baku mutu yang ditetapkan yakni dengan nilai pH 6 - 9.Dapat dilihat dari seluruh parameter awal limbah cair kopi ini masih belum layak untuk dibuang langsung ke lingkungan karena tidak masuk dalam baku mutu limbah cair kopi menurut Permen LH No. 5 Tahun 2014. 


\section{a. Suhu}

Suhu merupakan salah satu parameter yang mempunyai pengaruh terhadap aktivitas biota atau mikroorganisme yang ada di dalam air. Suhu juga dapat berpengaruh terhadap adanya kehidupan di dalam air sehingga secara langsung suhu juga berpengaruh terhadap keseimbangan oksigen didalam air Nilai suhu didapat dengan mengukur mengunakan termometer setiap hari selama waktu penelitian berdasarkan masing-masing waktu pemaparan tanaman. Adapun nilai suhu yang didapat sebagai berikut ;

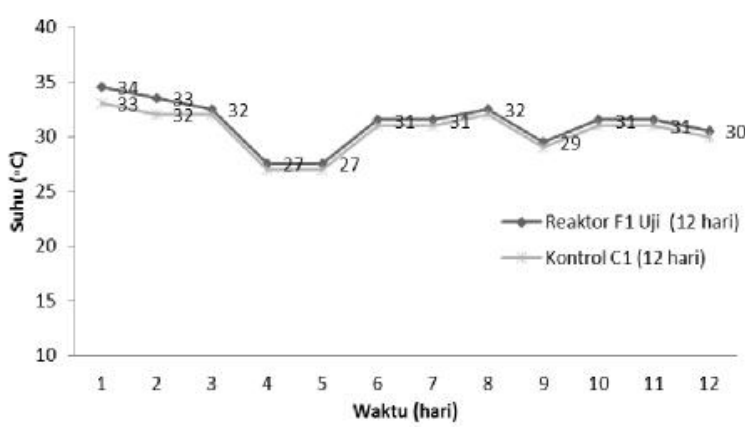

(a) Reaktor 12 hari

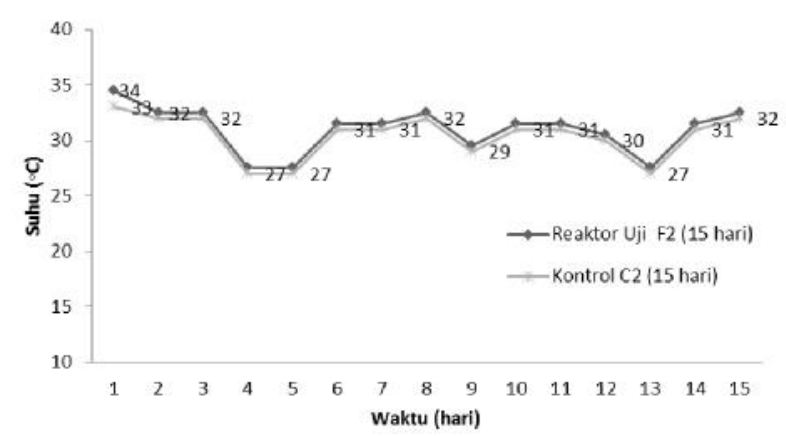

(b) Reaktor 15 hari

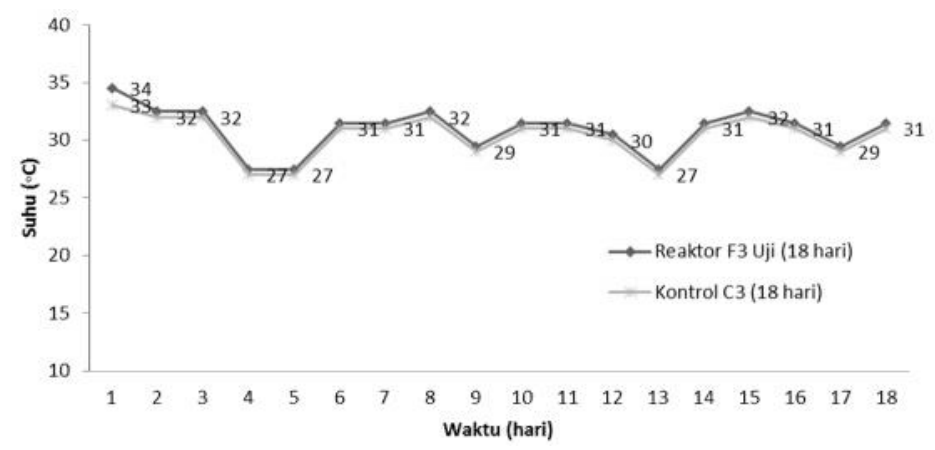

(c) Reaktor 18 hari

Gambar 2.Grafik Perubahan suhu reaktor

Berdasarkan Gambar 2 bagian (a), (b) dan (c) menunjukkan grafik perubahan suhu yang terjadi selama fitoremediasi berlangsung dalam reaktor kontrol dan reaktor uji berdasarkan variasi waktu pemaparan. Perubahan suhu pada masing-masing reaktor kontrol dan reaktor uji cenderung sama, hal ini dikarenakan suhu kedua jenis reaktor tersebut sangat dipengaruhi oleh kondisi suhu lingkungan dengan suhu rata-rata sebesar $30^{\circ} \mathrm{C}$ pada masing-masing reaktor, sehingga dapat dikatakan bahwa pada kondisi suhu tersebut merupakan kondisi yang baik bagi tanaman coontail untuk tumbuh dan berkembang. 


\section{b. $\quad \mathrm{pH}$}

$\mathrm{pH}$ didefinisikan sebagai logaritma dari aktifitas ion hidrogen $\left(\mathrm{H}^{+}\right)$yang terlarut yang mempunyai skala 0 - 14. Nilai $\mathrm{pH}$ didapat dengan mengukur $\mathrm{pH}$ air limbah pada tiap reaktor kontrol dan reaktor uji menggunakan $\mathrm{pH}$ meter setiap hari. Dari hasil pengukuran awal limbah cair kopi didapatkan $\mathrm{pH}$ awal yaitu 4,2 yang bersifat asam. Nilai pH dapat mempengaruhi pertumbuhan dan perkembangan tanaman. Pada nilai $\mathrm{pH}<4$ sebagian tumbuhan air akan mati karena tidak dapat bertoleransi terhadap $\mathrm{pH}$ yang terlalu rendah (Effendi, 2003). Berdasarkan hasil pengukuran awal menunjukkan bahwa limbah cair hasil pengolahan kopi bersifat asam dan tidak memenuhi baku mutu yang ditetapkan oleh Permen LH No. 5 Tahun 2014, sehingga tidak layak untuk dibuang langsung ke lingkungan. Berikut ini merupakan nilai pH yang didapat selama pengukuran :

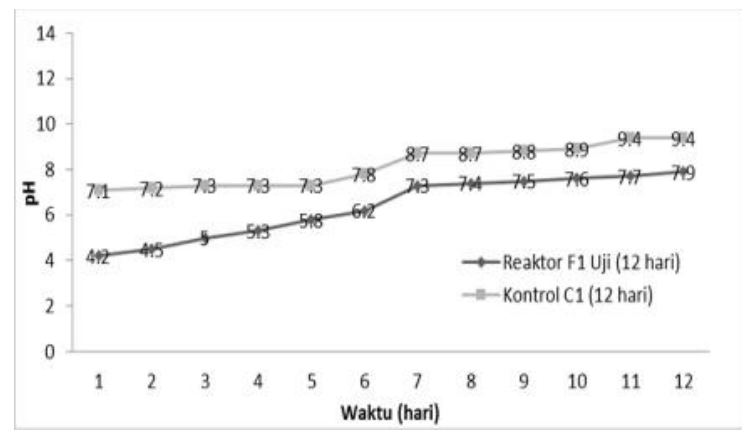

(a) Reaktor 12 hari

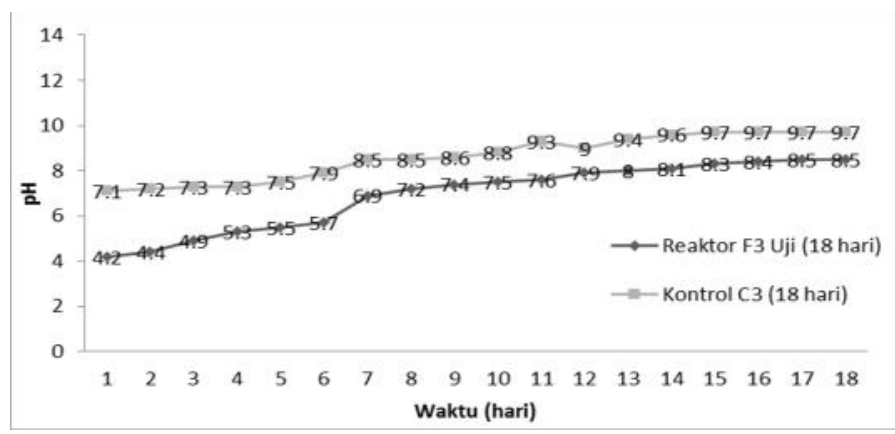

(c) Reaktor 18 hari

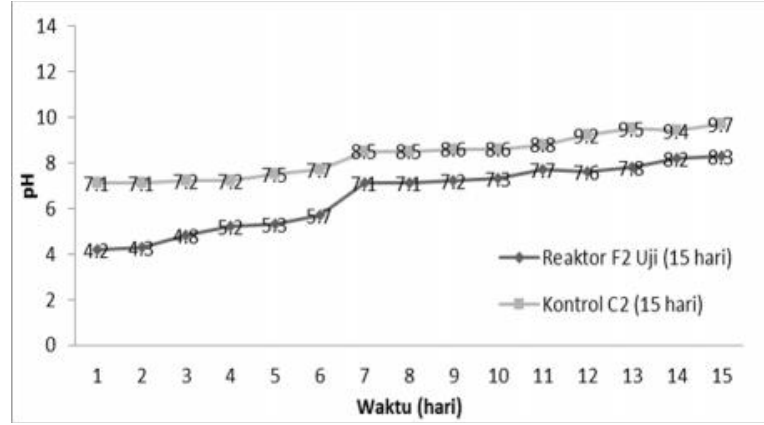

(b) Reaktor 15 hari

Gambar 3.Grafik Laju Kenaikan pH Reaktor

Berdasarkan Gambar 3 menunjukkan perubahan nilai pH tiap reaktor berdasarkan waktu pemaparan. Terjadi peningkatan nilai pH pada hari ke 12 sebesar 3,7 (dari 4,2-7,9), pada hari ke 15 sebesar 4,1 (dari 4,2-8,3), dan pada hari ke 18 mencapai 4,3 (dari 4,2 hingga 8,5). Perubahan derajat asam pada masing-masing reaktor disebabkan karena adanya proses fotosintesis dan respirasi pada tumbuhan atau mikroorganisme.

Pada dasarnya nilai pH erat kaitannya dengan nilai karbon dioksida (CO2). Semakin tinggi nilai karbondiosida (CO2) dalam air limbah maka akan semakin rendah nilai pH karena adanya proses pelepasan elekton dalam reaksi bikarbonat (Kordi et al, 2007). Berikut merupakan reaksi yang terjadi selama proses fotosintesis tanaman :

$$
6 \mathrm{H}_{2} \mathrm{O}+6 \mathrm{CO}_{2} \stackrel{\text { Tanaman }}{\longrightarrow} \mathrm{C}_{6} \mathrm{H}_{12} \mathrm{O}_{6}+6 \mathrm{O}_{2}
$$

Reaksi pada proses fotosintesis akan mengikat banyak senyawa $\mathrm{CO} 2$, yang akan berdampak pada terjadinya peningkatan nilai $\mathrm{pH}$ air. Kenaikan $\mathrm{pH}$ pada limbah cair terjadi karena adanya proses 
fotosintesis tanaman coontail. Pada saat berfotosintesis tanaman coontailakan mengikat banyak senyawa $\mathrm{CO} 2$ yang kemudian akan diubah menjadi monosakarida dan oksigen sehingga keberadaan $\mathrm{CO} 2$ pada limbah semakin berkurang dan berdampak pula pada peningkatan nilai $\mathrm{pH}$.

\section{c. BOD}

Kebutuhan oksigen biologi (BOD) didefinisikan sebagai banyaknya oksigen yang diperlukan oleh organisme pada saat pemecahan bahan organik pada kondisi aerobik. Analisis BOD dilakukan setiap 3 hari yaitu pada hari ke-12 setelah tanam, hari ke-15 setelah tanam, dan hari ke-18 setelah tanam. Adapun hasil uji laboratorium diperoleh data penurunan konsentrasi BOD limbah cair kopi selama proses fitoremediasi dapat terlihat pada Gambar 4 dan Tabel 2 berikut :

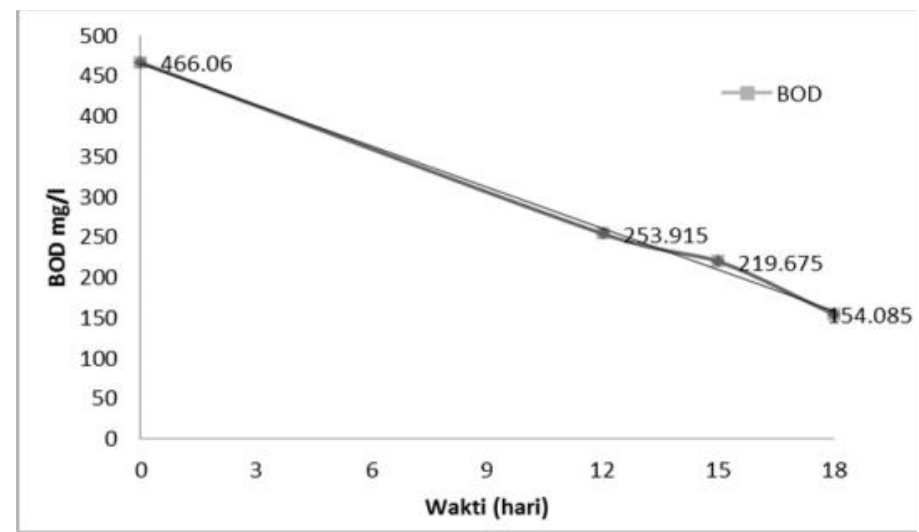

Gambar 4. Grafik Penurunan Nilai BOD

Seperti terlihat pada Gambar4 menunjukkan terjadi penurunan BOD dimulai pada hari ke 12 , 15 dan pada hari ke 18. Hal yang sama juga diungkapkan oleh Intansari dan Mangkoedihardjo, (2014) yang mengatakan bahwa tanaman coontail dapat menurunkan nilai BOD dengan waktu optimum pada hari ke-15. Tetapi pada hari ke 18 ternyata tanaman coontail masih mampu menurunkan parameter BOD lebih baik dari hari ke-15. Hal ini menunjukkan bahwa tanaman coontail pada rentan hari 12, 15, dan 18 masih mampu dengan baik menurunkan parameter BOD limbah cair kopi.

Tabel 2. Nilai Efisiensi Penurunan BOD

\begin{tabular}{|c|c|c|}
\hline Hari Ke & BOD (mg/L) & Efisiensi (\%) \\
\hline $\mathbf{0}$ & 466.06 & $0 \%$ \\
\hline $\mathbf{1 2}$ & 253,915 & $45,51 \%$ \\
\hline $\mathbf{1 5}$ & 219,675 & $52,86 \%$ \\
\hline $\mathbf{1 8}$ & 154,085 & $66,93 \%$ \\
\hline
\end{tabular}

Pada Tabel 2 menunjukkan besarnya nilai efisiensi penurunan nilai BOD mulai dari hari pertama hingga hari ke-18. Setelah dilakukan perhitungan menggunakan rumus efisiensi didapatlah nilai efisiensi dari masing-masing reaktor uji dimana, nilai efisiensi terbesar ditunjukkan oleh F3 dengan nilai efisiensi tertinggi sebesar $66,93 \%$ dengan lama waktu tinggal 18 hari. Penurunan nilai BOD ini disebabkan karena tanaman coontail merupakan tanaman yang mempunyai kemampuan yang baik dalam berfotosintesis sehingga tanaman coontail mampu mensuplai kadar oksigen yang tinggi dan dapat meningkatkan kadar oksigen terlarut didalam air dan menciptakan kondisi aerobik 
yang dapat mendukung aktivitas mikroorganisme aerob untuk menurunkan kandungan BOD pada limbah.

Penurunan nilai BOD dapat diindikasikan dengan besarnya senyawa organik yang terurai secara biologi (Apriadi, 2008). Hampir seluruh bakteri yang ada mampu menurunkan senyawa organik biodegradable terutama pada zona aerob. Dalam proses aerob dengan adanya oksigen, mikroba aerob akan mengoksidasi senyawa-senyawa organik membentuk sel-sel baru ke bentuk yang lebih stabil. Seperti pada persamaan reaksi berikut (Utami, 2000):

$$
\text { Senyawa organik }+\mathrm{O}_{2} \stackrel{\text { Mikroba }}{\longrightarrow} \mathrm{NH}_{3}+\mathrm{CO}_{2}+\mathrm{H}_{2} \mathrm{O}+\text { energi }
$$

Bakteri aerob umumnya hidup dengan menempel pada akar tanaman. Bakteri ini akan membantu tanaman dalam proses pemecahan senyawa organik menjadi lebih stabil sehingga dapat diserap oleh tanaman melalui akar.

\section{d. Pengamatan Morfologi Tanaman}

Dalam proses fitoremediasi menggunakan limbah cair kopi masing-masing bagian tanaman coontail menunjukkan respon yang diakibatkan adanya penyerapan bahan organik oleh tanaman. Bagian-bagian yang diamati pada tanaman coontail adalah perubahan warna, struktur batang, dan akar tanaman.Sedangkan kondisi limbah cair kopi terlihat keruh berwarna hitam kecoklatan, serta berbau seperti biji kopi mentah. Pengamatan warna tanaman diamati dengan melihat secara lansung perubahan warna daun tanaman dari awal hingga akhir proses fitoremediasi berdasarkan lama waktu tinggal pada setiap reaktor. Pengamatan struktur batang tanaman dilihat dengan mengukur panjang tanaman menggunakan penggaris serta dengan melihat kondisi batang tanaman secara kasat mata seperti terlihat pada Gambar 5berikut :

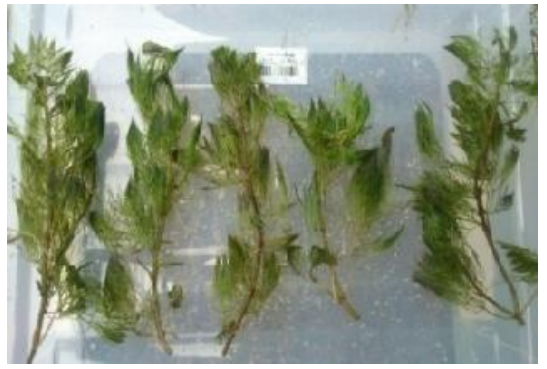

(a) Hari ke 0

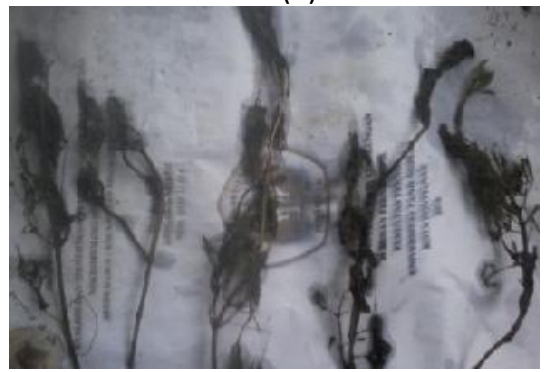

(b) Hari ke 15

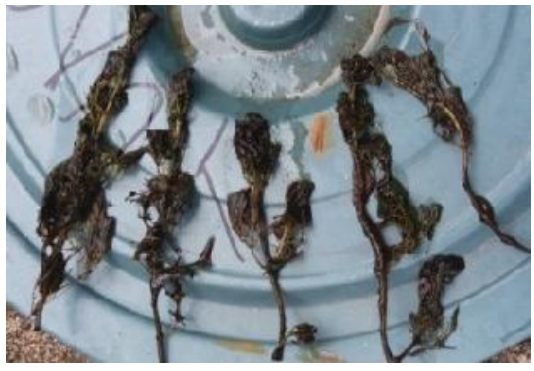

(b) Hari ke 12

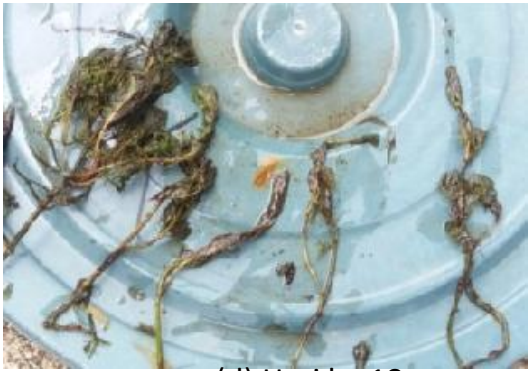

(d) Hari ke 18

Gambar 5. Perubahan Warna Daun Tanaman Coontail

Terihat dalam Gambar 5 menunjukkan perubahan warna tanaman pada awal hingga pada akhir proses fotosintesis. Terjadi perubahan warna tanaman pada masing-masing reaktor berdasarkan lama waktu pemaparan tanaman. Terlihat, tanaman yang awalnya terlihat masih segar dengan kondisi daun berwarna hijau pada akhir-akhir fitoremediasi menunjukkan kondisi tanaman yang telah berubah warna menjadi layu, berwarna coklat kehitamanserta batang yang terlihat 
kurus.Dalam proses fitoremediasi limbah cair kopi dengan tanaman coontail terjadi proses fitoakumulasi dan fitodegradasi yang terjadi pada tanaman (Rossiana, 2007) sehingga menyebabkan perubahan warna serta struktur batang tanaman coontail.

Tabel 3. Perubahan Panjang Tanaman Coontail Selama Fitoremediasi

\begin{tabular}{|c|c|c|}
\hline No & Waktu Tinggal (Hari) & Panjang Tanaman (cm) \\
\hline 1 & 0 & 10 \\
\hline 2 & 12 & $12-13$ \\
\hline 3 & 15 & $12-14$ \\
\hline 4 & 18 & $13-14$ \\
\hline
\end{tabular}

Terihat dalam Tabel 3 menunjukkan perubahan panjang batang tanaman pada awal hingga pada akhir proses fotosintesis. Terjadi perubahan panjang tanaman pada masing-masing reaktor berdasarkan lama waktu pemaparan tanaman.Terlihat, tanaman yang awalnya berukuran $10 \mathrm{~cm}$ mengalami peningkatan panjang hingga dapat mencapai $14 \mathrm{~cm}$ pada hari ke-18.Kondisi batang tanaman yang awalnya terlihat hujau sbesar, pada akhir fitoremediasi terlihat kecil dan berwarna hitam kecoklatan. Pertambahan panjang tanaman dipengaruhi oleh proses fitoakumulasi dan fitodegradasi serta dapat pula dipengaruhi oleh kemampuan akar tanaman dalam menyerap unsur hara dalam limbah karena semakin banyak serabut akar tanaman maka akan semakin baik pula tanaman dalam menyerap bahan organik (Rahmah, 2014).

\section{- KESIMPULAN}

Berdasarkan hasil penelitian dan pembahasan yang telah dilakukan, dapat diambil beberapa kesimpulan sebagai berikut:

a. Fitoremediasi limbah cair kopi menggunakan tanaman coontail mampu menurunkan parameter BOD serta dapat meningkatkan nilai pH limbah dengan nilai efisiensi BOD pada hari ke 12 sebesar 45,5\% (dari 466,06 hingga 253,915) dan pH sebesar 3,7 (dari 4,2-7,9), BOD pada hari ke 15 sebesar 52,86\% (dari 253,915 hingga 291,075) dan pH sebesar 4,1 (dari 4,2 8,3 ), serta BOD pada hari ke 18 sebesar 66,94\% (dari 291,075 hingga 154,085) dan nilai pH mencapai 4,3 (dari 4,2 hingga 8,5).

b. Tanaman coontail (Ceratophyllum Demersum) mampu menurunkan nilai BOD tertinggi pada hari ke 18 dengan nilai efisiensi sebesar 66,94\% (dari 291,075 hingga 154,085) dengan nilai kenaikan pH mencapai 4,3 (dari 4,2 hingga 8,5).

\section{- UCAPAN TERIMAKASIH}

Penulis mengucapkan terimakasih kepada bapak Mursalim selaku pemiik perkebunan kopi yang telah mau meluangkan waktu dan berbagi ilmu tentang pengolahan kopi, mulai dari proses pemetikan hingga ke proses penggilingan biji kopi. Penulis juga mengucapkan banyak terimakasih kepada ibu Isna Apriani ST., M.Si., selaku dosen pembimbing utama dan Ulli Kadaria, ST., MT., selaku dosen pembimbing kedua serta kepada Yulisa Fitrianingsih, ST., MT., selaku dosen penguji utama dan Aini Sulastri, S.Si., M.Si., selaku dosen penguji kedua yang telah banyak memberikan saran dan masukan selama pengerjaan skripsi dan jurnal ini. Tak lupa penulis juga mengucapkan banyak terimakasih kepada seluh keluarga, terutama pada kedua orang tua dan kakak tercinta yang telah memberikan motivasi, dukungan dan doa. Serta kepada kawan-kawan fakultas teknik dan kepada 
semua pihak yang telah membantu, mendukung, memotivasi memberi masukan dan saran yang tidak dapat saya sebutkan satu persatu penulis ucapkan terimakasih banyak kepada kalian semua

\section{- DAFTAR PUSTAKA}

Apriadi, Tri. 2008. Kombinasi Bakteri Dan Tumbuhan Air Sebagai Bioremediator Dalam Mereduksi Kandungan Bahan Organik Limbah Kantin.IPB. Bogor

Effendi, H. 2003. Telaah Kualitas Air. Yogyakarta : Kanisiuus.

Intansari, Kartika.K dan Mangkoedihardjo, S, 2014. Uji Removal BOD dan COD Limbah Cair Tahu dengan Fitoremediasi Sistem Batch Menggunakan Tumbuhan Coontail (Certophyllum Demersum).Surabaya : Institut Teknologi Sepuluh November.

Kordi, K., Gufran, K. dan Tancung, A. 2007. Pengolahan Air Terpadu.Yogyakarta : Penerbit Andi.

Mahdalena.2014. Pengaruh Suhu Terhadap Produksi Biogas Pada Proses Metanogenesis Berbahan Limbah Cair Kelapa Sawit. Medan, Universitas Sumatera Utara.

Rahmah, H. 2014. Fitoremediasi Limbah Cair Mocaf Dengan Menggunakan Tanaman Eceng Gondok (Eichornia Crassipes (Mart.) Solms). Skripsi. Jember: Fakultas Teknologi Pertanian, Jurusan Teknik Pertanian Universitas Jember.

Rossiana, N., Supriatun, T. dan Dhahiyat Y. 2007. Fitoremediasi Limbah Cair Dengan Eceng Gondok (Eichornia Crassipes (Mart.) Solm) dan Limbah Padat Industri Minyak Bumi Dengan Sengon (Paraserianthes Falcataria L. Nielsen) Bermikoriza. Laporan Penelitian. Bandung : FMIPAUniversitas Padjajaran.

Utami Sri, Budiati., (2000), " Penurunan Kadar COD Limbah Cair Tekstil Dengan Proses Anaerob dan Anaerob Menggunakan Lumpur Aktif ",LaporanPenelitian, Teknik Kimia, Universitas Diponegoro.

Widyotomo, S. 2012. Potensi dan Teknologi Diversifikasi Limbah Kopi MenjadiProduk Bermutu Dan BernilaiTambahHttp://Iccri.Net/Download/Pelita\%2OPerkebunan/Vol\%2027\%20No\%201\%20Apr il\%20201//5.\%20sksn \%20FINAL-Sksn\%20\%28Rev\%29.pdf. 